\title{
POLITYKA
}

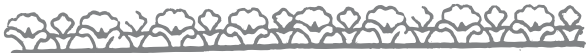

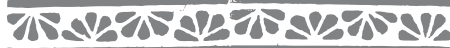 \\ Adam W. Jelonek

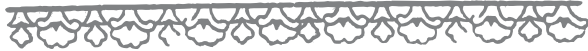

\section{KRYZYS KONSOCJONALNEJ DEMOKRACJI. PRZYPADEK FIDŻI}

\section{Demokracja w społeczeństwach heterogenicznych}

Badacze systemów politycznych często odnosili stabilność ustroju demokratycznego do struktury i charakteru podziałów występujących w społeczeństwie. Względna jednorodność systemów społecznych, jak zakładali, stanowiła jeden z istotnych czynników przyczyniających się do budowy stabilnej demokracji. Heterogeniczne systemy społeczne natomiast, z trudem, jeśli w ogóle, stanowić mogły podatny grunt dla procesów demokratyzacji ${ }^{1}$.

Zwolennicy poglądu, że demokracja rozwijać się może niezależnie od głębokości podziałów etnicznych, rasowych i religijnych, wskazują na występowanie całkiem licznych tzw. społeczeństw pluralnych, które pomimo to wypracowały modele spełniające zasadnicze warunki demokratycznego normatywu. Wyraźnie wyodrębnione wspólnoty językowe w Szwajcarii, wielość segmentów składających się na struktury społeczne Belgii (w postaci tzw. familles spirituelles) czy Holandii (w postaci tzw. zuilen), dowodzą istnienia bardzo silnie sfragmentaryzowanej kultury politycznej. Pomimo to zarówno Szwajcaria, Belgia, jak i Holandia, zaliczane są do grupy państw o najbardziej stabilnych systemach demokratycznych na świecie.

Hipotezę, starającą się wyjaśnić te odstępstwa, sformułowali m.in. Gabriel A. Almond i Sidney Verba w The Civic Culture. Być może, przypuszczają Almond i Verba, państwom tym udało się wypracować swoja własnq wersję kultury politycznej $i$ stworzyć praktykę dostosowania sprzeczności przenikajacych społeczeństwo, prowadzq-

${ }^{1}$ Douglas W. Rae, Michael Taylor, The analysis of political cleavages, Yale University Press, New Haven 1970, s. 5-16. 
cq do instytucjonalnego kompromisu ${ }^{2}$. Verba uważa, że w przypadkach tak zwanych sfragmentowanych demokracji, społeczeństwa dzielą się na dwa zamknięte i izolowane obozy. Można przypuszczać, że kanały komunikacji pomiędzy tymi obozami istnieją jedynie na poziomie najściślejszego przywództwa obydwu grup. Uprawianie polityki w takim systemie przypomina prowadzenie negocjacji między rywalizujacymi państwami, kiedy to załamanie się negocjacji i wojna sq zawsze możliwe. Mówiąc słowami Verby, niestabilność takich systemów ma charakter endemiczny ${ }^{3}$. Jest nie tylko możliwa, ale wysoce prawdopodobna, $\mathrm{z}$ drugiej strony jednak nie jest nieunikniona. Przywódcy rywalizujących ze sobą grup, jeśli są tylko świadomi zagrożeń, mogą podejmować działania zmierzające do przeciwdziałania destabilizacji. Dahl zauważa, że możliwość przemocy $i$ wojny domowej zawsze stanowi zagrożenie w krajach z wrogimi sobie subkulturami, a zagrożenie to bez watpienia stymuluje do poszukiwań alternatywnych rozwiazañ ${ }^{4}$.

W tym samym kierunku w swych poszukiwaniach poszedł także Arend Lijphart - współtwórca terminu „konsocjonalna demokracja”, odnoszącego się do działania mechanizmów demokratycznych w społeczeństwach pluralnych. Podobnie jak Dahl twierdzi on, że odśrodkowe tendencje typowe dla społeczeństwa pluralnego są równoważone przez postawę i zachowania kooperacji przywódców różnych segmentów populacji ${ }^{5}$. Lijphart kontynuując tok rozumowania Almonda i Verby zauważa, że zwykło się traktować zasadę podejmowania decyzji przez większość jako zupełnie naturalny warunek konieczny dla funkcjonowania systemów demokratycznych. Zasada większości, kontynuuje Lijphart, w ramach tak zwanego systemu demokracji majorytarnej (westminsterskiej) wyłącza mniejszości z procesu podejmowania decyzji. We względnie homogenicznych społeczeństwach zasada ta nie budzi na ogół wątpliwości. W większości systemów majorytarnych wyłączenie mniejszościowej opozycji z procesu podejmowania decyzji ma charakter przejściowy. Partie opozycyjne mogą w nadchodzących wyborach zdobyć większość głosów lub utworzyć koalicję gwarantującą im udział w procesie podejmowania decyzji.

Jednakże w społeczeństwach, w których głębokość podziałów przekroczy pewną masę krytyczną, zachowanie klasycznego modelu majorytarnego ma głębokie konsekwencje dla samego ducha demokracji. Jak wskazuje Arend Lijphart, w społeczeństwach głęboko podzielonych według kryteriów religijnych, językowych, etnicznych czy rasowych władza większości jest nie tylko niedemokratyczna, ale również niebezpieczna, ponieważ mniejszości w trwały sposób są wyłączane z procesu politycz-

${ }^{2}$ Gabriel A. Almond, Sidney Verba, The civic culture: Political attitudes and democracy in five nations, Princeton Univeristy Press, Princeton 1963, s. 111.

3 Tamże, s. 135.

${ }^{4}$ Robert A. Dahl, Polyarchy: Participation and opposition, Yale University Press, New Haven 1971, s. $110-111$.

${ }_{5}$ Arend Lijphart, Definitions, evidence, and policy, “Journal of Theoretical Politics", Volume 12, 4/2000; Arend Lijphart, Democracies : patterns of majoritarian and consensus government in twenty-one countries, Yale University Press, New Haven 1984. s. 22. 
nego, a tym samym czują się marginalizowane i dyskryminowane. Utrzymywanie się modelu majorytarnego w takich społeczeństwach, zdaniem Patricka Moynihana, nieuchronnie prowadzić musi do kryzysu systemu, jego dezintegracji, upadku procedur demokratycznych, a prawdopodobnie też do eskalacji przemocy ${ }^{6}$. Zwolennicy rozwiązania konsocjonalnego twierdza, że występująca wśród elit politycznych poszczególnych segmentów społeczeństw pluralnych dyspozycja do nieustannego poszukiwania kompromisu umożliwia nie tylko unikanie otwartych konfliktów, ale także zachowanie standardów demokratycznych. Reprezentacje polityczne poszczególnych segmentów społeczeństwa muszą nieustannie odwoływać się do dwóch wymiarów - wewnętrznego, koncentrującego się na reprezentacji własnego segmentowego elektoratu, i zewnętrznego, oscylującego wokół poszukiwania porozumienia z reprezentantami pozostałych segmentów społecznych ${ }^{7}$.

Zwolennicy koncepcji konsocjonalizmu posługują się szerokim materiałem empirycznym dla dowiedzenia potencjalnych możliwości zachowania systemowego porozumienia i zinstytucjonalizowanej demokracji w społeczeństwach pluralnych. Często przywołują wspomniane już przeze mnie na wstępie przykłady Belgii, Holandii czy Szwajcarii, jako dowody na to, że demokracja w społeczeństwach pluralnych ma szanse. Niestety, praktyka pokazuje, że demokracja i stabilność społeczeństw wieloetnicznych, wieloreligijnych czy wielorasowych rzadko chodzą ze sobą w parze.

Krytycy koncepcji konsocjonalnej demokracji dostarczają niezliczonych przykładów załamania się społecznego konsensusu lub/i upadku procedur demokratycznych, właśnie w społeczeństwach pluralnych ${ }^{8}$. Niejasne i mało przekonywujące są argumenty teoretyków konsocjonalizmu co do fukcjonowania konsocjonalnej demokracji w Kanadzie, podzielonej na segmenty anglo- i frankofoński ${ }^{9}$. Katastrofą i wybuchem wojny domowej zakończyły się próby budowy konsocjonalnego porozumienia oraz wprowadzenia systemu demokratycznego w wielowyznaniowym Libanie czy na wieloetnicznym Cyprze ${ }^{10}$. Stopniową erozją rozwiązań demokratycznych, a także wprowadzeniem instytucji dyskryminujących mniejszość chińską i indyjską zakończyły się próby zbudowania opartego na konsensusie systemu politycznego w Male$\mathrm{zj}^{11}$. Nie nastrajają też do optymizmu niedawne niepowodzenia wspólnoty między-

${ }^{6}$ Daniel P. Moynihan, Pandemonium: Ethnicity in international politics, Oxford University Press, New York 1993, s. 54.

${ }^{7}$ Kurt R. Luther, Kris Deschouwer, Party elites in divided societies: Political parts in consociational democracy, Routledge, London 1999, s. 5-16.

${ }^{8}$ Eric Nordlinger, Isolationism reconfigured, Princeton University Press, Princeton 1996.

9 Kenneth McRae, Conflict and compromise in multilingual societies, Wilfrid Laurier Press, Ontario 1983, s. 26-87.

${ }^{10}$ Meir Zamir, Lebanon's quest : The road to statehood, Negev 2003, s. 207-219. Anna Jarstad, Changing the game: Consociational theory and ethnic quotas in Cyprus and New Zealand. Department of Peace and Conflict Research. Report no.58, Uppsala 2001, s. 267-275.

${ }^{11}$ Adam W. Jelonek, Dylematy konsocjonalizmu. Przypadek Malezji, Instytut Socjologii UW, Warszawa 2004; Diane K. Mauzy, Challenges to the multi-ethnic stability in Malaysia, Singapore 1983, s. $18-43$. 
narodowej w budowie systemów demokratycznych w pluralnych społeczeństwach Iraku, Afganistanu, czy na Bałkanach ${ }^{12}$. Dla wielu krytyków teorii konsocjonalnej modelowy wręcz przykład załamania się systemu demokratycznego i kryzysu społeczeństwa pluralnego stanowi wieloetniczne Fidżi.

\section{Spuścizna kolonialna, a system społeczeństwa pluralnego na Fidzii}

Zrozumienie charakteru współczesnego systemu politycznego Fidżi wymaga analizy dynamiki kształtujących go relacji pomiędzy wspólnotami etnicznymi, zamieszkującymi archipelag. Nieodzowna dla osiaggnięcia tego celu jest krótka retrospekcja historii osadnictwa na wyspach i polityki kolonialnej, która na trwałe uformowała segmentowy charakter społeczeństwa i pluralny kształt systemu politycznego.

Fidżi jest krajem położonym na archipelagu 322 wysp w południowej części Oceanu Spokojnego. Zdecydowana większość populacji żyje na dwóch głównych wyspach Viti Levu i Vanua Viti. Społeczeństwo Fidżi od lat stanowi złożoną mozaikę zróżnicowanych wewnętrznie grup etnicznych i religijnych. Archipelag zamieszkały jest obecnie w większości (54,3\%) przez rdzenną ludność fidżyjską o mieszanym polinezyjsko-melanezyjskim pochodzeniu. Prócz niej na wyspach żyje duża wspólnota indyjska $(38,1 \%)$, składająca się z potomków robotników sprowadzonych przez brytyjską administrację kolonialną w XIX w. Na Fidżi spotykamy również inne mniejszości, w tym potomków osadników z Europy i Chin. Podziały etniczne pokrywają się z grubsza z podziałami religijnymi. Etniczni Fidżyjczycy są w ogromnej większości chrześcijanami $(97,2 \%)$, podczas gdy mniejszość indyjska wyznaje indyjizm $(70,7 \%)$ i islam $(17,9 \%)$.

Przed kolonizacją organizacja polityczna Fidżi była całkowicie zdecentralizowana. Składało się nań szereg lokalnych wspólnot plemiennych. Mataqali (rody oparte na patriarchacie) łączyły się w yavusa (klany), te z kolei tworzyły wspólne vanua ( państwa ), które łączyły się w konfederacje matanitu ${ }^{13}$. W połowie XIX w. najsilniejsze z nich, położone we wschodnich prowincjach kraju, rozpoczęły trwającą kilkadziesiąt lat wojnę o dominację nad całym archipelagiem. Ze wschodnich prowincji pochodzi również wspólny język fidżyjski bauan, który w tym samym czasie zaczął się upowszechniać. Prawdziwe zjednoczenie kraju i wprowadzenie jednolitej administracji przyniosła jednak dopiero kolonizacja brytyjska ${ }^{14}$.

${ }^{12}$ R. Hislope, Political corruption and interethnic coalitions: The crisis in Macedonia, Paper prepared for workshop "The Clandestine Political Economy of War and Peace: Insights from the Balkans", Brown University, New York 2003; Jurg Steiner, Responses to critiques of consociational theory, "Acta Politica", 37/2002, s. 236.

${ }_{13}$ David Stanley, Fiji handbook, Moon Publications, Chico, CA 1999, s. 50.

${ }^{14}$ Stephanie Lawson, Tradition versus democracy in the South Pacific: Fiji, Tonga and Western Samoa, Cambridge University Press, Cambridge 1996, s. 54. 
Wielka Brytania przejęła formalną kontrolę nad wyspami w 1874 r., lecz pierwsi europejscy osadnicy - początkowo kupcy i misjonarze - zaczęli się tam pojawiać już pod koniec XVIII w. Wzrost kontaktów handlowych i intensywna kolonizacja kraju przypada jednak dopiero na pierwsze dekady XIX w. Brytyjczycy dla wzmocnienia swojej pozycji w regionie umiejętnie wykorzystywali toczące się wówczas walki pomiędzy konfederacjami i próby przeciwstawienia się dominacji przybyszy z sąsiednich wysp Tonga. Już pod koniec lat 60 . XIX w. władze w Londynie zdecydowały się bezpośrednio zaangażować w konflikt toczący się między tongijskim wodzem Ma'afu i samozwańczym Tui Viti (królem) Fidżi - Ratu Seru Cakobau ${ }^{15}$. W rozbitym na dwa państewka kraju przedstawiciele brytyjscy mogli swobodnie rozgrywać wewnętrzne konflikty. Ostatecznie rządzący wschodem Fidżi Ratu Seru Cakobau w zamian za udzielone mu wsparcie postanowił oddać swe państwo pod opiekę Londynu ${ }^{16}$. Akt przekazania z 10 października 1874 r., przyjęty oficjalnie przez gubernatora Nowej Południowej Walii, mówił o bezwarunkowym zrzeczeniu się przez wszystkich przywódców plemiennych suwerenności nad wyspami na rzecz królowej Wiktorii i zdaniu się na jej opiekę i sprawiedliwośćc ${ }^{17}$.

Akt przekazania zawierał w paragrafie 7. istotne z punktu widzenia rdzennej ludności zamieszkującej wyspy postanowienie, mówiące iż prawa i interesy króla Fidżi (Tui Viti) oraz innych przywódców plemiennych będq w petni respektowane, jeśli nie będzie to pozostawać w sprzeczności z brytyjska suwerennościq nad wyspami ${ }^{18}$. Na straży przywilejów rdzennej ludności stać miała specjalnie w tym celu powołana Wielka Rada Przywódców Plemiennych. Władze brytyjskie zobowiązywały się też nie ingerować w lokalny, tradycyjny system władzy plemiennej.

Izolacja społeczności plemiennych na Fidżi i białych osadników stawała się podstawą prowadzonej przez władze kolonialne polityki ${ }^{19}$. Za oficjalnie głoszonym hasłem ochrony lokalnej kultury przed zewnętrznymi wpływami kryło się formowanie się dwóch niezależnie od siebie żyjących społeczności - rdzennych mieszkańców Fidżi i białych kolonistów. Obie wspólnoty budowały własne, niezależne od siebie instytucje społeczne, polityczne i kulturowe. Obie też, zdaniem władz kolonialnych, realizować miały zupełnie odmienne zadania.

Sir Arthur Hamilton Gordon, pierwszy kolonialny gubernator Fidżi, i jego następca na urzędzie, Sir John Thurston, niebawem mieli jednak podjąć działania, które całkowicie zmieniły etniczny charakter wyspy i zagroziły interesom lokalnych przywódców. Realizując politykę wyznaczoną przez brytyjskie Ministerstwo d.s. Kolonii, gubernatorzy doszli do porozumienia z australijską Colonial Sugar Refining Compa-

${ }^{15}$ Brij V. Lal, Broken waves: A history of the Fiji Islands in the Twentieth Century. Hawai'i University Press, Honolulu 1992, s. 9.

16 Tamże, s. 11.

17 Tamże, s. 12.

18 Tamże.

19 S. Lawson, cyt. wyd., s. 46. 
ny (CSR) w sprawie budowy na wyspach pierwszych rafinerii cukru. Zakładanie na wyspach nowych plantacji trzciny cukrowej ściagnęło z Europy kolejną falę kolonistów oraz doprowadziło do znacznego wzrostu zapotrzebowania na tanią siłę roboczą, a tym samym do konieczności przynajmniej częściowej rewizji poglądów administracji brytyjskiej na kwestię izolacji wspólnot. Wprowadzone u progu XX w. ustawodawstwo zmniejszało bezwzględną władzę przywódców plemiennych, pozwalając po raz pierwszy na swobodne zatrudnianie się na plantacjach żonatym autochtonom. Ograniczano też wspólnotowy charakter gospodarki plemiennej, sankcjonujący na poły niewolnicze relacje pomiędzy fidżyjskim chłopstwem a tradycyjnymi naczelnikami wsi. Rozwiązania te zredukować miały w zamyśle władz brytyjskich rosnący deficyt rąk do pracy.

Problem ten zaczęto rozwiązywać równocześnie także i w inny sposób. W 1879 r. pod naciskiem białych kolonistów gubernator Arthur Gordon postanowił zasilić lokalny rynek pracy, umożliwiając masową imigrację robotników rolnych z Indii. W ramach systemu osadnictwa zwanego girmit, w ciagu 40 lat jego obowiązywania na wyspy Fidżi przybyło ponad 60 tysięcy pracowników z subkontynentu indyjskiego. System okazał się niezwykle korzystny dla białych plantatorów i przyczynił się do dynamicznego rozwoju gospodarki kolonii. Robotnicy rolni jeszcze w Indiach podpisywali pięcioletnie kontrakty (girmit) z właścicielami plantacji. Kontrakty przewidywały świadczenie pracy za symboliczne wynagrodzenie przez 9 godzin dziennie w dni robocze i 5 godzin w soboty. Na miejscu często okazywało się, że robotnicy musieli jeszcze pokrywać koszty zakwaterowania czy opieki medycznej, co w praktyce redukowało ich dochody do zera. Pracownicy z Indii, nie objęci żadną opieką ze strony państwa, zdani byli całkowicie na łaskę swoich panów. Śmiertelność na plantacjach pod koniec XIX w. sięgała kilkunastu procent ${ }^{20}$. System okazywał się tylko pod jednym względem korzystny dla przybyszy. Po zakończeniu pięcioletniego kontraktu robotnicy rolni (garmitya) mogli wydzierżawić ziemię od Korony, bądź od lokalnych wspólnot plemiennych i uprawiać ją na własny rachunek. Mimo że władze kolonialne proponowały indyjskim osadnikom po kolejnych pięciu latach powrót na koszt Korony do Indii, stosunkowo nieliczni decydowali się na skorzystanie z tej możliwości ${ }^{21}$. Indusi osiedlali się na wyspach na stałe. Początkowo zajmowali się uprawą niewielkich poletek trzciny cukrowej. $\mathrm{Z}$ czasem otwierali drobne, rodzinne przedsiębiorstwa. W 1887 r. na 49 wydanych licencji na handel uliczny aż 20 przypadło Indusom. W r. 1900 niemal cały handel i usługi znalazły się w rękach przybyszy z Indii. Statystyki z 1911 r. podają, że na 25.976 Indusów, zamieszkujących na archipelagu Fidżi, rolnictwem zajmowało się zaledwie $10.357^{22}$.

${ }^{20}$ B. V. Lal, cyt. wyd., s. 41.

${ }^{21}$ Tamże, s. 39.

22 Tamże; A. Ali, Society in transition: aspects of Fiji-Indian history, 1879-1939. University of the South Pacific, Suva 1976, s. 8. 
Likwidacja systemu kontraktowego girmit nie stała się przeszkodą dla dalszej dynamicznej imigracji na Fidżi przybyszy z subkontynentu indyjskiego. W latach 20. i 30. na wyspy przybywało coraz więcej wolnych Indusów, skuszonych pogłoskami o możliwościach łatwego zdobycia pracy i lepszych zarobków. O ile w 1921 r. na Fidżi zamieszkiwało 60 tys. Indusów, to w $1936 \mathrm{r}$. ich liczba sięgnęła 85 tys. ${ }^{23}$. We wspólnocie indyjskiej dokonywały się też poważne przeobrażenia społeczne i kulturalne. Przed r. 1920 wspólnota ta była społecznie izolowana, uzależniona ekonomicznie, kulturowo zdezorientowana, zaś politycznie zdezorganizowana i pozbawiona głosu. Brak jej było niezależnego przywództwa i reprezentacji we władzach kolonii. Lata 20. przynosić zaczęly stopniowe zmiany ${ }^{24}$.

Władze brytyjskie z mieszanymi uczuciami przyglądały się indyjskiemu osadnictwu na wyspach. Jako wyjątkowo zróżnicowana - pochodząca z wielu regionów kraju, reprezentująca różną przynależność kastową i wyznaniową - wspólnota indyjska nie stanowiła bezpośredniego zagrożenia dla władzy kolonialnej, mogła jednak taką się stać w przyszłości. Obawiano się zagrożenia kultury rdzennej ludności przez rosnąca grupe przybyszy, co w dalszej perspektywie groziło wzrostem napięć międzyetnicznych. Tymczasem za wspieraniem indyjskiej imigracji przemawiały argumenty ekonomiczne. Brytyjczycy mieli świadomość, że przemysł cukrowniczy - główne źródło dochodów białych mieszkańców wysp - nie ma szans przetrwania bez stałego napływu robotników z Indii. Kolonizacja indyjska oparta na systemie girmit przebiegała zatem w sposób niczym niezakłócony do $1920 \mathrm{r}$. Spowodowana nią zmiana struktury etnicznej kraju wywarła poważny wpływ na XX-wieczną historię kraju i jego system polityczny.

\section{Polityka kolonialna i jej wpływ na relacje etniczne na Fidzii}

Brytyjska polityka wobec poszczególnych grup etnicznych zamieszkujących Fidżi od początku kształtowała wzajemne postrzeganie ludności rdzennej i przybyszy z subkontynentu. Jak już wspomniałem, pierwsi gubernatorzy głosili doktrynę pełnej izolacji poszczególnych wspólnot, uzasadniając ją różnymi funkcjami, jakie każda z nich miała spełniać w wykreowanym w ten sposób systemie społecznym. Przesycone stereotypami poglądy władz kolonialnych na temat rzekomej natury Fidżyjczyków i Indusów oraz reprezentowanych przez nich kultur wywierały również trwały wpływ na kształtowanie się tożsamości etnicznej obydwu grup.

Władze brytyjskie w ślad za gubernatorem Gordonem uważały, że rdzenna ludność reprezentuje unikalną kulturę, której należy się ochrona. Najlepszym sposobem na jej przetrwanie miała być ścisła jej izolacja od niepotrzebnych kontaktów, zarówno z białymi kolonistami, jak i napływającymi robotnikami z Indii. Autochto-

${ }^{23}$ B. V. Lal, cyt. wyd., s. 74.

24 Tamże, s. 75. 
ni mieli mieszkać w zamkniętych wspólnotach. Długo uważano, że dopuszczanie ich do pracy na równi z Indusami może, żeby użyć słów samego gubernatora Gordona, przyczynić się do ich społecznego zatonięcia w masie imigrantów. Rzadziej formułowane opinie wręcz podawały w wattpliwość zdolność autochtonów do przetrwania poza własnymi wspólnotami wiejskimi. W poufnych raportach administracji kolonialnej wielokrotnie czytamy o niskim poziomie intelektualnym rdzennych Fidżyjczyków, ich lenistwie, małej wytrzymałości i ogólnie niewielkich szansach wykorzystania ich jako pracowników ${ }^{25}$. Odmiennie, choć równie stereotypowo, oceniano przybyszy z subkontynentu. Jeden z brytyjskich urzędników kolonialnych, Morgan Finucane, opisywał ich jako przebiegła, wytrzymała i pracowita masę, pozbawioną jakiejkolwiek kultury ${ }^{26}$.

W oczach Brytyjczyków obydwie grupy zamieszkujące wyspy były tak różne od siebie, że nigdy nie powinny żyć ze sobą razem. Zdaniem Stephanie Lawson, trwałe przekonanie władz brytyjskich o homogenicznym charakterze obydwu grup doprowadziło ostatecznie do realizacji ...scenariusza samospetniajacego się proroctwa we wprowadzaniu polityki separacji obu grup etnicznych i wtórnym stworzeniu specyficznej ideologii tych grup ${ }^{27}$.

Koloniści brytyjscy również starali się utrzymywać stan wygodnej samoizolacji. W myśl obowiązujących rozporządzeń ludność kolorowa nie miała prawa osiedlać się w bezpośrednim sąsiedztwie siedzib ludności białej czy w centrach miast. Przez długi czas ścisły system segregacji rasowej utrzymywał się w szkolnictwie. Władze kolonii w raportach wielokrotnie zresztą dawały znać o tym, że nie życzą sobie nadmiernie wykształconej siły roboczej, która stanowić by mogła zagrożenie dla pokoju spolecznego na wyspach ${ }^{28}$.

Brytyjska administracja kolonialna całkowicie kontrolowała realny system władzy na wyspach. Zarówno autochtoni, jak i Indusi, pozbawieni byli praw wyborczych. Czynne prawo wyborcze przysługiwało jedynie umiejacym czytać i pisać poddanym króla brytyjskiego [...] o europejskim pochodzeniu, którzy ukończyli 21 lat i posiadali własność ziemskq umożliwiająca im płacenie podatków. Jednak pomimo że ludność rdzenna uzyskała prawa wyborcze dopiero w 1963 r., już znacznie wcześniej mogła liczyć na pewien ograniczony udział we władzy. Nie można tego powiedzieć o mniejszości indyjskiej. Deklaracja Urzędu Sekretarza d/s Kolonii z 1922 r. w sposób nie budzący żadnych wątpliwości wykluczała Indusów z jakichkolwiek form życia politycznego na wyspach: (Brytyjczycy) będa przeciwstawiać się, jak również wspomagać opór rdzennych mieszkańców Fidżi, przy użyciu wszelkich możliwych środków, przeciwko jakimkolwiek próbom uzyskania przez naplywowa ludność indyjskq dostę-

\footnotetext{
25 Tamże, s. 13.

26 Tamże, 39.

27 S. Lawson, cyt. wyd., s. 42.

28 B. V. Lal, cyt. wyd., s. 35.
} 
pu do urzędów publicznych i zobowiazuja się do nie przyznawania (tej wspólnocie) jakiegokolwiek statusu politycznego ${ }^{29}$.

Deklaracja ta była odpowiedzią na pierwsze próby organizowania się wspólnoty indyjskiej, połączone z coraz bardziej otwartym domaganiem się przez nią wpływu na decyzje podejmowane przez rząd. Urząd Sekretarza d/s Kolonii już w 1910 r. odnotowywał, że przyjmuje rosnaca liczbę petycji dotyczacych rozmaitych problemów społecznych, polityki gruntami i kwestii reprezentacji politycznej wspólnoty indyjskiej ${ }^{30}$. W 1929 r. utworzono wprawdzie przy gubernatorze specjalne stanowisko Sekretarza d/s Indyjskich, który miał „opiekować się” imigrantami i reprezentować ich interesy na forum lokalnego rządu, jednak obecność rosnącej grupy przybyszów z subkontynentu indyjskiego na scenie politycznej była wciąż niemal niezauważalna ${ }^{31}$.

W polityce wewnętrznej Brytyjczycy nadal uznawali, że konieczne jest zachowywanie jasno wyznaczonych granic poszczególnych segmentów społeczeństwa pluralnego, sami zaś przyjęli rolę rozjemcy i gwaranta spokoju społecznego na wyspach. W myśl tej doktryny Indusi mieli zachować ściśle podporządkowany status, a ich przedstawiciele zostać na trwałe pozbawieni jakiegokolwiek udziału we władzy. Doktryna ta stanowiła główny filar organizacji życia politycznego w kolonii. Działo się tak niezależnie od ponawianych z Londynu zapewnień, że Indusi jako poddani korony brytyjskiej powinni cieszyć się takimi samymi prawami, jak inni obywatele Imperium ${ }^{32}$.

Ducha tych rozwiązań nie zmieniły też przeprowadzane stopniowo zmiany w systemie administracji państwowej. Władza wykonawcza w kolonii, sprawowana przez mianowanego przez Londyn gubernatora oraz Radę Ministrów aż do lat 40., stanowiła wyłączną domenę europejskich osadników i działała tylko w ich interesie. Wprowadzenie zaś w 1929 r. do Rady Ustawodawczej równych, 5-osobowych reprezentacji wszystkich trzech wspólnot zamieszkujących wyspy, miało znaczenie czysto symboliczne.

Pierwsze partie polityczne na Fidżi powstawać zaczęły na gruncie coraz silniejszej rywalizacji pomiędzy poszczególnymi segmentami społeczeństwa pluralnego. Założony w 1954 r. przez Ratu Sir Lala Sukuna Związek Fidżi (Fijian Association) stawiał sobie za cel wspieranie brytyjskiego gubernatora w walce z żądaniami Indusów o uzyskanie większego wpływu na decyzje w państwie. Powstała w odpowiedzi Narodowa Partia Federacji (National Federation Party - NFP) stanowiła luźne ugrupowanie indyjskich organizacji hodowców trzciny cukrowej, reprezentujące interesy przybyszy z subkontynentu.

10 października 1970 r. Fidżi uzyskało niepodległość w ramach Brytyjskiej Wspólnoty Narodów, przejmując od metropolii parlamentarny system rządów. Sir Ratu

\footnotetext{
29 Tamże, s. 87.

${ }^{30}$ Tamże, s. 40-41.

31 Tamże, s. 79.

${ }^{32}$ S. Lawson, cyt. wyd., s. 52.
} 
George Cakobau, wnuk pierwszego króla Fidżi Ratu Seru Cakobau, został pierwszym gubernatorem generalnym niepodległego państwa. System etnicznej separacji ustanowiony przez Brytyjczyków nadal kształtował jednak wzajemne relacje pomiędzy zamieszkującymi go wspólnotami i nie pozostał bez wpływu na kształt jego sceny politycznej.

\section{Kryzysy demokracii w wieloetnicznym Fidżi}

W 1966 r. doszło do próby powołania pierwszej partii wieloetnicznej - Partii Związku (Alliance Party). Ugrupowanie formalnie stanowiło koalicję trzech partii etnicznych: reprezentującego białych kolonistów Związku Wyborczego (General Electors' Association), niewielkiego Związku Indusów Fidżi (Fiji Indian Alliance) oraz Związku Fidżi (Fijian Association), inicjatora utworzenia nowej partii. Partia Związku wbrew nazwie nie stała bynajmniej na stanowisku konieczności rzeczywistego zjednoczenia wszystkich mieszkańców wyspy. Jej powstanie było odpowiedzią na coraz wyraźniejsze sukcesy indyjskiej etnicznej Narodowej Partii Federacji. Partia Związku promowała w swoim programie ścisłą separację wszystkich wspólnot etnicznych, a kluczowe stanowiska zajmowali w niej przywódcy plemienni ze wschodnich prowincji. Na czele partii stanął nacjonalistyczny działacz obrony praw ludności rdzennej Ratu Sir Kamisese Mara, któremu po uzyskaniu przez kraj niepodległości przypadło stanowisko pierwszego premiera kraju. Część działaczy partyjnych, takich jak Sakiasi Butadroka, głosiło poglądy skrajnie szowinistyczne, wzywając wprost do ostatecznego rozwiqzania kwestii indyjskiej i przymusowej repatriacji wszystkich „obcych” do kraju ich pochodzenia. Wielu polityków fidżyjskich skrycie podzielało opinie Butadroki, choć poprawność polityczna nie pozwalała im na otwartą aprobatę. Jego apele wygłaszane na wiecach spotykały się jednak z masowym poparciem szerokich rzesz rdzennych Fidżyjczyków ${ }^{33}$.

W 1975 r. Butadroka zdecydował się na utworzenie własnego ugrupowania Nacjonalistycznej Partii Fidżi, głoszącej otwarcie hasło konieczności czystek etnicznych na wyspie. Choć jego partii nie udało się odnieść spektakularnego sukcesu w wyborach z kwietnia 1977 r., jej działalność skutecznie osłabiła reprezentację Partii Związku w parlamencie. Na dominującą siłę ponownie wyrastała Narodowa Partia Federacji, kierowana przez Sidiq Koya, przywódcę indyjskich muzułmanów. W rezultacie kwietniowych wyborów dysponowała ona większością 26 miejsc w 50-osobowej Izbie Reprezentantów. Możliwość powołania na stanowisko premiera przedstawiciela Indusów wywołało masowe protesty. Gubernator generalny Fidżi, starając się zażegnać narastający kryzys w państwie, zrezygnował z mianowania premierem przywódcy większości parlamentarnej, godząc się tym samym na rząd mniejszościowy,

\footnotetext{
33 B. V. Lal, cyt. wyd., s. 235.
} 
kierowany przez Ratu Mara, przywódcę Partii Związku. Kolejne wybory, przeprowadzone zaledwie w pięć miesięcy później, pozwoliły w wyniku zmasowanej kampanii propagandowej na ponowne zdobycie większości parlamentarnej przez Partię Związku. Obie elekcje w 1977 r. ukazały jednak rzecz znamienną dla fidżyjskiej sceny politycznej: rdzenna ludność i jej działacze nie byli skłonni do zaakceptowania sytuacji, w której władza znalazłaby się w rękach ugrupowania reprezentującego ludność indyjską. Brak akceptacji przekładał się w takich przypadkach na kontestowanie rezultatów samego aktu wyborczego - jeśli tylko nie był on po myśli rdzennych mieszkańców wyspy ${ }^{34}$.

Partii Związku udało się zachować swój stan posiadania i większość parlamentarną w kolejnych wyborach 1982 r. Odwrót Indusów od NFP, nękanej waśniami pomiędzy wyznawcami indyjizmu i muzułmanami, oraz skuteczna mobilizacja rdzennej ludności pod nacjonalistycznymi hasłami przez Partię Związku pozwoliły na zachowanie stanu równowagi politycznej, definiowanego w ten sposób, że partia rządząca reprezentuje z natury rzeczy Fidżyjczyków, a partia opozycyjna Indusów ${ }^{35}$. Sytuacja ta miała jednak wkrótce się zmienić.

W lipcu 1982 r. doszło do powstania kolejnej, tym razem rzeczywiście wieloetnicznej Partii Pracy Fidżi (Fiji Labour Party - FLP), kierowanej przez pochodzącego z rdzennej ludności dr Timoci Uluivuda Bavadrę. Choć ugrupowanie w znacznej mierze stanowiło spadkobiercę elektoratu NFP, jako pierwsze w historii sceny politycznej państwa znacznie mniej koncentrowało się na podziałach etnicznych. Program Partii Pracy kładł nacisk przede wszystkim na zwalczanie nierówności ekonomicznych, niekoniecznie pokrywających się z podziałami narodowościowymi ${ }^{36}$. FLP przyznawała się do programu „demokratycznego socjalizmu”, a jej głównymi hasłami w kampanii stały się walka o sprawiedliwość społeczną i zrównoważony rozwój gospodarczy oraz eliminacja wciąż obecnych nierówności pomiędzy wschodnimi i zachodnimi prowincjami państwa ${ }^{37}$. Partia Pracy szybko zaczęła zdobywać poparcie nie tylko rozczarowanych do działań NFP Indusów, ale też zubożałych przedstawicieli rdzennej ludności fidżyjskiej.

W 1986 r. Partia Pracy przed zbliżającymi się wyborami utworzyła koalicję z osłabionym NFP (działającą pod nazwą Partii Koalicyjnej lub w skrócie Koalicji). Kampania wyborcza 1987 r. przebiegła w atmosferze niespotykanej dotychczas walki i wzajemnych oskarżeń pomiędzy wieloetniczną Koalicją NFP-FLP a Partią Związku. Program tej ostatniej nadal stał na gruncie utrzymywania separacji grup etnicznych, a wypowiedzi jej przywódców pełne były ksenofobicznych ostrzeżeń kierowanych pod adresem swego elektoratu. Przypominano, że ewentualna zmiana partii rządzącej musi doprowadzić do podważenia praw rdzennej ludności, pogorszenia się

\footnotetext{
34 Tamże, s. 241.

35 S. Lawson, cyt. wyd., s. 61.

36 Tamże, s. 62.

37 B. V. Lal, cyt. wyd., s. 258.
} 
jej warunków życia i szybkiej utraty ziemi oraz miejsc pracy na rzecz ludności indyjskiej. Koalicja zarzucała partii rządzącej tolerowanie szerzącej się korupcji, w tym samego premiera Mary. Występowała też ostro przeciwko tradycyjnym przywilejom przywódców plemiennych ${ }^{38}$.

W wyborach z kwietnia 1987 r. Koalicja odniosła sukces. Ugrupowanie zdobyło 28 miejsc w 52-osobowej Izbie Reprezentantów, pozostawiając 24 mandaty Partii Związku. Znaczna część mieszkańców Fidżi uważała, że powtórzy się scenariusz z 1977 r. i władza przypadnie ponownie ugrupowaniu mniejszościowemu. Ku zaskoczeniu wszystkich 13 kwietnia Bavadra został zaprzysiężony na stanowisku premiera ${ }^{39}$.

Fakt ten wywołał poważne zaniepokojenie części mieszkańców Fidżi. Wkrótce po ogłoszeniu wyników wyborów przegrana Partia Związku zaczęła organizować protesty, demonstracje i blokady dróg w stolicy państwa Suvie. 21 kwietnia grupa jej radykalnych działaczy, zgromadzonych pod domem Bavadry, odczytała deklarację o stanie zagrożenia żywotnych praw rdzennej ludności, będących rezultatem indyjskich machinacji ${ }^{40}$. Dokument powoływał do życia nową organizację quasi-partyjną - Ruch Społeczny Taukei (od słowa taukei - oznaczającego fidżyjskich chłopów). Ruch stawiał sobie za cel koordynowanie działań zmierzających do obalenia rządów Koalicji. 24 kwietnia pod hasłami Fidżi dla Fidżyjczyków i Indusi do domu ulicami stolicy kraju przeszła czterotysięczna manifestacja, której uczestnicy zaczęli podpalać budynki rządowe i niszczyć indyjskie sklepy. Kraj stanął na krawędzi wojny domowej. Stanowiło to dogodny pretekst do interwencji sił zbrojnych. 14 maja $1987 \mathrm{r}$. oddziały ówczesnego podpułkownika Sitiveni Rabuki wkroczyły do budynku parlamentu i dokonały aresztowania deputowanych wybranych z list Koalicji. Rabuka zawiesił władzę gubernatora generalnego kraju i unieważnił konstytucję w imię ochrony spokoju społecznego i zagwarantowania zagrożonych praw ludności fidżyjskiej.

Zamachowi stanu przeciwstawiły się liczne środowiska polityczne. Fidżyjski Sąd Najwyższy uznał działania wojskowych za niekonstytucyjne. Zaprotestował reprezentujący na wyspie królową Elżbietę II gubernator generalny Ratu Sir Penaia Ganilau. Zainicjowane przez niego rozmowy między przywódcami Koalicji i Partii Związku zakończyły się względnym sukcesem. Zawarte przez zwaśnione strony 23 września kompromisowe porozumienie z Dabua mówiło o utworzeniu koalicyjnego rządu zgody narodowej pod kierunkiem samego gubernatora Ganilau. Porozumienie z Dabua po raz pierwszy w historii kraju dawało nadzieję na wprowadzenie na wyspie rozwiązań rzeczywistej konsocjonalnej demokracji. Rodziła się możliwość porozumienia skłóconych do tej pory elit politycznych obydwu wspólnot etnicznych. Nowy rząd nigdy jednak nie powstał...

25 września podpułkownik Rabuka zdecydował się na przeprowadzenie kolejnego zamachu stanu. Drugi zamach stanu miał o wiele bardziej gwałtowny przebieg.

\footnotetext{
38 Tamże, s. 263.

39 Tamże, s. 265.

40 Tamże, s. 272.
} 
W całym kraju wprowadzono godzinę policyjną i zakaz podróżowania. Wojsko przejęło kontrolę nad stacjami radiowymi i wkroczyło do redakcji opozycyjnych gazet. 7 października 1987 r. kraj został proklamowany republiką, a w dwa dni później wykluczony z Brytyjskiej Wspólnoty Narodów.

Rabuka wyznaczył dotychczasowego gubernatora generalnego Ratu Ganilau na stanowisko prezydenta i powołał przywódcę Partii Związku, Ratu Mara, na premiera. Nowy rząd był w istocie zakładnikiem wojskowego reżimu. Pięciu jego członków stanowili działacze kontrolowanego przez Rabukę Ruchu Społecznego Taukei, którego publiczne wypowiedzi przyczyniały się do nieustannego podsycania waśni etnicznych i powodowały coraz wyraźniejszy opór ze strony wspólnoty indyjskiej ${ }^{41}$. Wydarzenia z 1987 r. oznaczały załamanie niestabilnego stanu równowagi w państwie. Dowodziły też niewattpliwie silnych animozji pomiędzy obydwoma segmentami społeczeństwa. Pokazywały również, jak łatwo za pomocą podsycania owych animozji udaje się manipulować opinią publiczną, a tym samym jak wątłe są podstawy systemu demokratycznego w kraju.

Drugi zamach, podobnie zreszta jak pierwszy, przeprowadzono w imię obrony interesów rdzennej ludności fidżyjskiej. W jego rezultacie wszystkie ziemie należące dotychczas do Korony - w tym dzierżawione przez Indusów - zostały przekazane w ręce autochtonów. W kraju przez cały czas obowiązywały przepisy stanu wojennego, często wykorzystywane do dyskryminacji ludności indyjskiej. Protestujący byli brutalnie przesłuchiwani i więzieni. Rewidowano i rabowano indyjskie domy. Rozporzq̨dzenie o bezpieczeństwie (Internal Security Degree - ISD), które weszło w życie w czerwcu 1988 r., pozwalało na prewencyjne zatrzymanie bez procesu na okres do 2 lat. Nowe przepisy pozwalały też na niszczenie i palenie w majestacie prawa świątyń indyjskich jako potencjalnych zarzewi antyrządowych spisków ${ }^{42}$.

W warunkach obowiązujących wciąż przepisów stanu wojennego Fidżi przyjęło 25 lipca 1990 r. nową konstytucję. Dokument sankcjonował separację etniczną i w poważny sposób dyskryminował ludność indyjską. Ustawa zasadnicza wprowadzała dwuizbowy parlament. Do jego izby niższej wybory odbywać się miały w oparciu o wspólnotowy (kurialny) system wyborczy. W oparciu o niego wyborcy z danej grupy etnicznej mogli głosować wyłącznie na przedstawicieli własnej grupy. W 69osobowej Izbie Reprezentantów nowy system wyborczy gwarantował 37 miejsc ludności rdzennej wyspy. W mianowanym w całości przez prezydenta 34-osobowym senacie 24 członków stanowić mieli przedstawiciele fidżyjskich przywódców plemiennych. Prezydent, wybierany również przez przywódców plemiennych, miał powoływać premiera spośród etnicznych Fidżyjczyków. Wielka Rada Przywódców Plemiennych wniosła do konstytucji artykuł o chrześcijańskim charakterze państwa, co oznaczało pośrednią dyskryminację indyjskiej i muzułmańskiej ludności z subkonty-

${ }^{41}$ R. T. Robertson, Multiculturalism \& reconciliation in an indulgent republic: Fiji after the coups: 1987-1998, Fiji Institute of Applied Studies, Suva 1998, s. 38-40.

42 Tamże, s. 47. 
nentu indyjskiego. Znalazł się w niej również zapis, że jedynie przedstawiciele ludności rodzimej mogą piastować najwyższe stanowiska w państwie. Dla Fidżyjczyków zastrzeżono m.in. funkcje ministra finansów, spraw zagranicznych, przemysłu, spraw wewnętrznych, a także stanowiska dowódcy sił zbrojnych i komendanta policji ${ }^{43}$. W zgodnej opinii obserwatorów nowa konstytucja miała na celu stopniowa eliminację wspólnoty indyjskiej z życia politycznego kraju. Jej przepisy instytucjonalizowały system jednopartyjny w państwie. Od tej chwili każdy rząd mógł być powoływany bez poparcia przedstawicieli ludności indyjskiej ${ }^{44}$.

Na scenie politycznej pojawiła się nowa, dostosowana do aktualnego systemu politycznego partia Soqosoqo ni Vakavulewa ni Taukei (SVT) znana też pod nazwą Partii Fidżi. Niemal wszyscy jej członkowie rekrutowali się z szeregów ludności autochtonicznej, a większość działaczy stanowili politycy Partii Związku. Na czele ugrupowania stanął sam inicjator zamachu, major Rabuka. Po wyborach 1992 r. partia zdominowała całkowicie scenę polityczną państwa, zdobywając 30 z 37 miejsc dla etnicznych Fidżyjczyków w parlamencie, a jej przywódca objął w czerwcu 1992 r. funkcję premiera ${ }^{45}$.

Pod naciskiem wspólnoty międzynarodowej już w 1995 r. postanowiono jednak rozpocząć próby uzupełnienia i zmiany dotychczasowej ustawy zasadniczej. Nowy projekt, podpisany ostatecznie przez prezydenta Marę w czerwcu 1997 r., łagodził nieco system politycznego apartheidu. Przyjmował częściowe odejście od wspólnotowego charakteru głosowania. Część miejsc w parlamencie obsadzana miała być nadal w wyborach kurialnych, zwiększano jednak liczbę mandatów z okręgów wieloetnicznych. Liczba zagwarantowanych dla autochtonów miejsc w parlamencie ulegała znaczącemu obniżeniu z 37 do 23 . Z konstytucji wykreślono też zapis o konieczności obsadzania stanowiska premiera przez etnicznego Fidżyjczyka ${ }^{46}$.

Zmiany w konstytucji przyczyniły się do poprawy ogólnego klimatu politycznego w państwie. Reprezentacje obu grup etnicznych podejmowały chętniej współpracę na forum parlamentu. Władze kraju poprzez wykreślenie dyskryminujących wobec wspólnoty indyjskiej zapisów w ustawie zasadniczej podreperowały nieco swoją nadszarpniętą pozycję na arenie międzynarodowej, czego rezultatem stało się powtórne przyjęcie Fidżi w skład Brytyjskiej Wspólnoty Narodów oraz odblokowanie środków pomocowych przez rządy Australii i Nowej Zelandii. Koncesje poczynione przez rząd Sitiveni Rabuki doprowadziły jednak do znaczącego spadku jego poparcia we wspólnocie rdzennej ludności fidżyjskiej. W połowie 1998 r. jego popularność w społeczeństwie spadła do rekordowo niskiego poziomu 29\%. Stopniowo odzyskiwała natomiast znaczenie całkowicie do tej pory zmarginalizowana, zdominowana przez Indusów Partia Pracy ${ }^{47}$.

\footnotetext{
43 Tamże, s. 56-59.

${ }^{44}$ S. Lawson, cyt. wyd., s. 66.

${ }^{45}$ R. T. Robertson, cyt. wyd., s. 98.

${ }^{46}$ D. Stanley, Fiji handbook, Moon Publications, Chico, CA 1999, s. 43.

${ }^{47}$ R. T. Robertson, cyt. wyd., s. 184.
} 
Pierwsze wybory, przeprowadzone w maju 1999 r. w oparciu o zmienioną konstytucję, miały się stać ważnym testem nowych, względnie kompromisowych rozwiązań w systemie politycznym wyspy. Po przeliczeniu głosów okazało się, że kierowana przez Mahendrę Chaudhry'ego Partia Pracy odniosła spektakularne zwycięstwo. Indyjskie ugrupowanie, głoszące hasła współpracy pomiędzy wspólnotami etnicznymi zamieszkującymi wyspę, zdobyło 37 miejsc w 71-osobowej Izbie Reprezentantów, pozostawiając głównego konkurenta Partię Fidżi z zaledwie 8 mandatami. Pozwalało to Partii Pracy na samodzielne sformowanie rządu. Poszerzenie koalicji o Związek Fidżi i kilka mniejszych partii dawało dotychczasowej opozycji stabilną większość 52 miejsc w parlamencie. 18 maja prezydent Kamisese Mara desygnował przywódce Partii Pracy na stanowisko premiera. Choć nowa konstytucja formalnie umożliwiała objęcie stanowiska premiera przez Indusa, a sam Chaudhry deklarował umiarkowaną politykę współpracy wszystkich sił parlamentarnych, znaczna część fidżyjskiego elektoratu ponownie zareagowała na ten fakt z wyraźną wrogością. Nawet część jego kolegów partyjnych i partnerów koalicyjnych ze Związku Fidżi publicznie zaczęła deklarować, że dla stabilności sytuacji bezpieczniej byłoby, gdyby przywódca Partii Pracy sam zrezygnował z misji formowania rządu ${ }^{48}$.

Obawy okazały się uzasadnione. Rząd Partii Pracy przetrwał niespełna rok, a w kraju powtórzył się nieco zmodyfikowany scenariusz sprzed kilkunastu lat. 19 maja 2000 r. grupa spiskowców kierowana przez Georga Speighta, powołując się na zagrożenie interesów rdzennych Fidżyjczyków przez wieloetniczny rząd Chaudhry’ego, dokonała kolejnego zamachu stanu. Mimo iż spiskowców aresztowano, władza ponownie znalazła się w rękach armii. Kierujący nowym reżimem wojskowym komandor Frank Bainimarama zawiesił obowiązywanie przepisów kompromisowej konstytucji. W wyborach, przeprowadzonych we wrześniu 2001 r. pod kontrolą wojska, zwycięstwo odniosła ponownie etniczna Partia Fidżi, kierowana przez nowego przywódcę Laisenia Qarase's. Fidżi po kolejnym, czwartym już z kolei zamachu stanu, przeprowadzonym 5 grudnia 2006 r., wciąż znajduje się pod kontrolą wojskowego reżimu.

\section{Konkluzje}

Teoria konsocjonalizmu szeroko posługuje się pojęciem społeczeństwa segmentowego (pluralnego) ${ }^{49}$. Rozumie przez to społeczeństwo złożone z kilku całkowicie samowystarczalnych, oddzielonych od siebie subkultur, o własnej organizacji, a także oddzielnych instytucjach życia kulturalnego i politycznego. W konsekwencji potencjalne napięcia między nimi znajdują wyraz niemal na wszystkich płaszczyznach -

${ }^{48}$ Robert Keith Reid, Fiji swears in as first Prime Minister from Indian minority, The Associated Press 1999.

${ }^{49}$ Rudy B. Andeweg, Consociational democracy, “Annual Review of Political Science”, 3/2000, s. 509-36. 
w partiach politycznych, grupach interesu czy mediach - wszędzie tam, gdzie przedstawiciele poszczególnych segmentów wchodzą ze sobą w interakcje. Do takich społeczeństw niewątpliwie zalicza się społeczeństwo fidżyjskie. Odziedziczony po Wielkiej Brytanii system separacji dwóch głównych wspólnot zamieszkujących wyspę $\mathrm{w}$ gruncie rzeczy funkcjonował wręcz w imię unikania etnicznych konfliktów i zachowania pokoju społecznego. Wielu badaczy społecznych starało się zresztą wspierać na gruncie teoretycznym tego rodzaju technikę społeczną. Ich zdaniem stabilność pluralnych systemów społecznych powinna rosnąć wraz z pogłębiającą się izolacją poszczególnych ich segmentów. Quincy Wright zauważyła: Ideologie przyjęte przez różne grupy, działajace w ramach jednego spoleczeństwa, mogq stać w sprzeczności wobec siebie, co niekoniecznie musi prowadzić do otwartych napięć... napięcia pojawiq się jednak, jeśli grupy te znajdq się w bliskim kontakcie ${ }^{50}$. Easton zaś stwierdził, że wysitki, zmierzajace do homogenizacji sfragmentaryzowanego systemu, nie musza być najlepszq droga do osiagnięcia jego stabilizacji... większe sukcesy można osiagnać poprzez podjęcie kroków, które doprowadza do wzrostu świadomości swego istnienia, a także wzajemnej odpowiedzialności, w ramach ściśle zamkniętych i odizolowanych od siebie jednostek kulturowych ${ }^{51}$. Pierwszy warunek konieczny, ujęty $\mathrm{w}$ normatywie sprawnego funkcjonowania systemu konsocjonalnej demokracji na Fidżi, wydawał się więc spełniony.

Zgodnie z przekonaniem klasyków konsocjonalizmu, funkcjonowanie systemu - wobec trwałej izolacji subkultur na poziomie mas - uzależnione jest od efektywnej kooperacji elit. Struktury artykulacji interesów nie przypominają w tym przypadku piramidy, ale wiele oddzielnych filarów. Współpraca ta stanowić ma mechanizm łączący szczyty filarów poszczególnych subkultur. Proces ten nazywany jest przez Lijpharta akomodacja elit. Funkcjonuje on jako substytut braku konsensusu politycznego na poziomie mas. W ręce elit powierzone zostaje zatem zarządzanie międzysegmentowym konfliktem, co dostarcza podstaw dla ograniczonej jedności politycznej. Odmiennie niż podzielone społeczności subkultur elity są w stanie, zdaniem Lijpharta, negocjować i osiagać kompromis. Wydaje się, że również ten warunek konsocjonalnego porozumienia do pewnego stopnia znajdował swój wyraz w ewolucji sceny politycznej na Fidżi. Elity obydwu wspólnot miały zbliżony status ekonomiczny. Coraz bardziej stawały się też świadome występujących zagrożeń dezintegracji całego systemu politycznego, z możliwością wojny domowej włącznie. Gdzie zatem można poszukiwać istoty katastrofy wieloetnicznej demokracji na wyspie?

Odpowiedzi wydaje się dostarczać sama teoria konsocjonalizmu. Jako podstawę dla instytucjonalnego rozwiązania Lijphart formułuje dwa warunki. Pierwszym jest

${ }^{50}$ Quincy Wright, The study of international relations, Appleton-Century Crofts, New York 1955, s. 18.

${ }^{51}$ David Easton, A systems analysis of political life, Wiley, New York 1965, s. 24; David Easton, Corinne Schelling, Social knowledge : balancing specialization and integration, Sage, Newbury Park 1990. 
współpraca elit poszczególnych segmentów sfragmentaryzowanego społeczeństwa dla osiagnięcia porozumienia politycznego (można to określić mianem solidarności horyzontalnej). Drugi warunek to zapewnienie sobie przez elity minimalnego stopnia poparcia, które pozwoli im na efektywne wcielanie w życie uzgodnionych uprzednio porozumień (co można określić jako wertykalną mobilizację społeczeństwa). Dobre relacje między elitami poszczególnych wyodrębnionych segmentów społeczeństwa są warunkiem koniecznym, jednak wcale nie wystarczającym dla sprawnego funkcjonowania systemu konsocjonalnej demokracji. Zachowania elit muszą uzyskiwać minimalny kredyt zaufania ze strony poszczególnych segmentów społeczeństwa. Niezależnie od tego masy muszą zachowywać lojalność wobec własnych elit. Dla stabilnego poparcia mas konieczna jest natomiast ich satysfakcja z bieżących i długofalowych konsekwencji podejmowanych przez elity rozwiązań. Posługując się słowami Hansa Daaldera, trwałość konsocjonalnej demokracji zależy nie tylko od tego, na ile przywódcy partii okażq się bardziej tolerancyjni niż ich zwolennicy, ale również od tego, na ile (przywódcy) będq w stanie utrzymać swoich zwolenników, czego w konsocjonalnym modelu na Fidżi zdawało się brakowaćs2. Takie nieco paradoksalne wytłumaczenie klęski porozumienia na scenie politycznej Fidżi dodaje do ogólnego katalogu warunków koniecznych stabilności konsocjonalnej demokracji jeszcze jeden. System polityczny społeczeństwa pluralnego zależy niewątpliwie od skuteczności izolacji poszczególnych jego segmentów. Bardziej jednak istotnym jego warunkiem jest wykształcenie przez poszczególne segmenty trwałych i stabilnych reprezentacji politycznych.

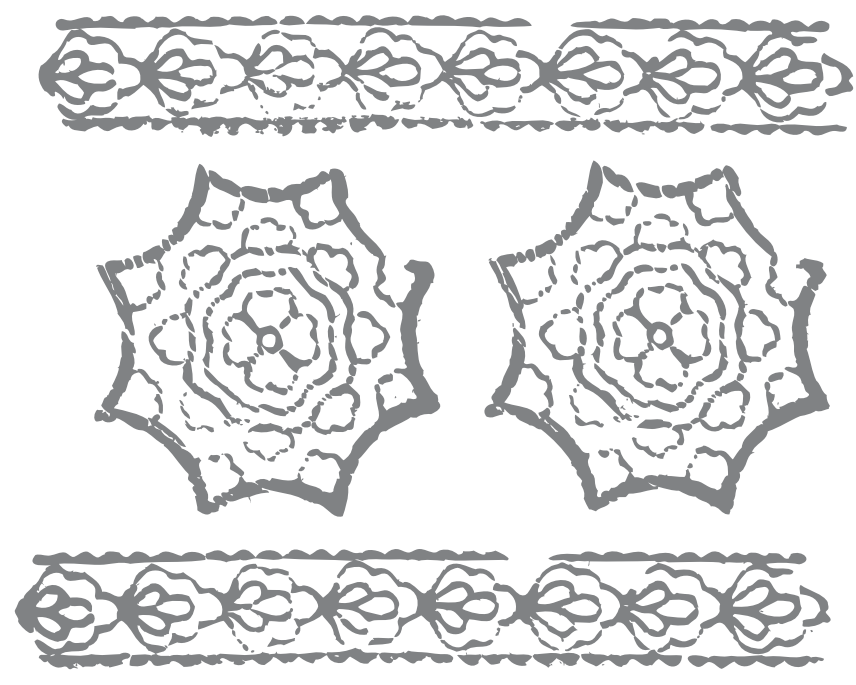

${ }^{52}$ Hans Daalder, Western European party systems: continuity and change, Sage Publ., London 1983, s. 56. 